\title{
ENVIRONMENTAL ASBESTOS POLLUTION - SITUATION IN POLAND
}

\section{NEONILA SZESZENIA-DĄBROWSKA ${ }^{1}$, WOJCIECH SOBALA ${ }^{1}$, BEATA ŚWIĄTKOWSKA ${ }^{1}$, GRAŻYNA STROSZEJN-MROWCA², and URSZULA WILCZYŃSKA ${ }^{1}$}

\author{
${ }^{1}$ Nofer Institute of Occupational Medicine, Łódź, Poland \\ Department of Occupational and Environmental Epidemiology \\ ${ }^{2}$ Nofer Institute of Occupational Medicine, Łódź, Poland \\ Department of Environmental Health Hazards
}

\begin{abstract}
Objectives: Environmental exposure of the general population to asbestos in Poland is mainly due to degradation of very popular asbestos-cement products and the resultant release of the elementary asbestos fibres into the ambient air. Assessments of environmental pollution by asbestos were based on the volume of the raw material used, amount of manufactured asbestos products, and measuring the concentration of fibres in the air. Material and Methods: Under the governmental program intended to remove asbestos, measurements of the concentration of asbestos fibres were performed in 2004-2010 in all provinces of Poland. Considering that potential sources of asbestos dust emissions were present in residential areas, 1634 sampling sites were designated. From 2 to 4 air samples were collected at each sampling site. A total of 5962 samples were collected during seven years. A single dose of air collected by $25 \mathrm{~mm} 0.8 \mu \mathrm{m}$ pore Sartorius filter was 1,300 litres. The fibres were counted using optical microscopy with phase contrast (PCM) on a polarizing microscope (PLM) at a total magnification of 600x.; method was adapted to determine the concentration of asbestos fibres in non-occupational environment. Results: Mean concentration of asbestos fibres was $492 \mathrm{f} / \mathrm{m}^{3}$ (95\% CI: 467-518). In $82 \%$ of the sampling sites, the mean concentrations did not exceed $800 \mathrm{f} /$ $\mathrm{m}^{3}$. As much as $25.8 \%$ of the samples were found to be below the detection limit of the method. Estimated mean concentrations of fibres in different provinces ranged from 146 (95\% CI: 106-203) to $709 \mathrm{f} / \mathrm{m}^{3}$ (95\% CI: 591-851). In the areas affected by former asbestos-processing plants, mean concentration was $732 \mathrm{f} / \mathrm{m}^{3}$ (95\% CI: 527-1016) and was significantly higher than levels recorded in other areas of Poland. Conclusion: Asbestos consumption per capita and the recorded moderate levels of asbestos fibres concentration in atmospheric air point to a relatively low level of environmental asbestos pollution in Poland.
\end{abstract}

Key words:

Asbestos consumption, Airborne asbestos fibres concentrations, Ambient air asbestos pollution,

Non-occupational asbestos exposure

\section{INTRODUCTION}

Import, production and trading of asbestos and asbestos-containing products has been banned in Poland since 1997 [1]. The parliamentary act prohibiting the use of asbestos products has solved the problem of the occupational exposure of the workers employed in the materials processing industry and banned the use and storage of the products. But the problem of enormous quantities of asbestos and asbestos-cement products for outdoor use remains to be solved yet.

The specific character of environmental pollution by asbestos, causing that it is particularly dangerous, results from the

This work was performed under the task "Assessment of environmental exposure to asbestos in Poland on the grounds of measurements of asbestos fibres concentration in ambient air" (IMP 10.2/2009).

Received: September 14, 2011. Accepted: September 19, 2011.

Address reprint request to N. Szeszenia-Dąbrowska, Department of Occupational and Environmental Epidemiology, Nofer Institute of Occupational Medicine, św. Teresy 8, 91-348 Łódź, Poland (e-mail: wies@imp.lodz.pl). 
fact that the asbestos fibres are practically indestructible, may be found in a diversity of products and are dispersed throughout the environment. It should be emphasized that all asbestos-containing products manufactured for long years have been located in the municipal environment and, in the course of their continuing degradation, have become a source of permanent emissions of elementary asbestos fibres into the ambient air. This has been aggravated in some areas by the use of the asbestos waste as a low-cost replacement material, i.e. to repair local roads. The magnitude of the exposure in a given area is difficult to define due to a high variability of asbestos fibres concentrations in ambient air and their relatively low concentrations. Please note, however, that much lower, relative to occupational, dust concentrations occurring in the environmental exposure do not exclude the risk of development of asbestos-related cancer. Environmental exposure differs from the occupational exposure in that it affects the general population and continues $24 \mathrm{~h} /$ day, 7 days/week, 365 days/year for ca. 30-40 years longer than the occupational exposure. The fibres accumulate in lung tissue throughout the lifetime of the individual. Thus, the cumulated dose may be high, even though the concentrations are moderate.

Environmental exposure to asbestos dust increases the risk of lung cancer; it may also cause mesothelioma and nonmalignant lesions in the pleura. The specific character of the biological activity of asbestos, essential for the determination of the health hazard to the population, comprises the following aspects: (1) very long latency period of the disease (up to 40 years), (2) the disease may develop after cessation of the exposure, (3) the development of mesotheliomas is associated with the environmental exposure after short-term exposures to high concentrations or prolonged contact with low concentrations of asbestos fibres.

\section{Consumption of asbestos}

In Poland, asbestos environmental pollution is mainly associated with the production and use of asbestos-cement products, such as roofing and cladding tiles (wall cladding panels) in the construction industry. Indoor exposure is not a major problem due to a limited use of soft asbestos formulations, such as e.g. spraying formulations, in construction materials for municipal use.

Asbestos-cement boards, extensively applied in the past, are classified as hard goods, i.e. products with a density exceeding $1000 \mathrm{~kg} / \mathrm{m}^{3}$ containing less than $20 \%$ solid-bound asbestos. In the boards produced in Poland, asbestos content ranged from $11 \%$ to $13 \%$ [2]. Till late 70 's, crocidolite was also used in the production of asbestos boards in addition to the chrysotile asbestos [3]. Crocidolite was used also for production of pipes, which contained up to $25 \%$ asbestos. In the mid-80's, the use of crocidolite was discontinued. Overall, after 1945, Poland imported 2 million tonnes of asbestos. About 1.5 million tonnes, including 86 thousand tonnes of crocidolite asbestos, were used for the production of asbestos-cement materials [4]. In the 1960-1970, annual consumption of asbestos increased by 12 thousand tonnes, since 1978 the consumption continued to decline at a rate of 5.4 tonnes per year until the end of production in 1998. At the peak in the 70's of the last century, 100 thousand tonnes of asbestos were used annually for the manufacture of asbestos-cement products, while in the 90's the use gradually declined (Figure 1). According to the 2004 estimate, 14.9 million tonnes, i.e. about 14000000 thousand $\mathrm{m}^{2}$ of asbestos-cement

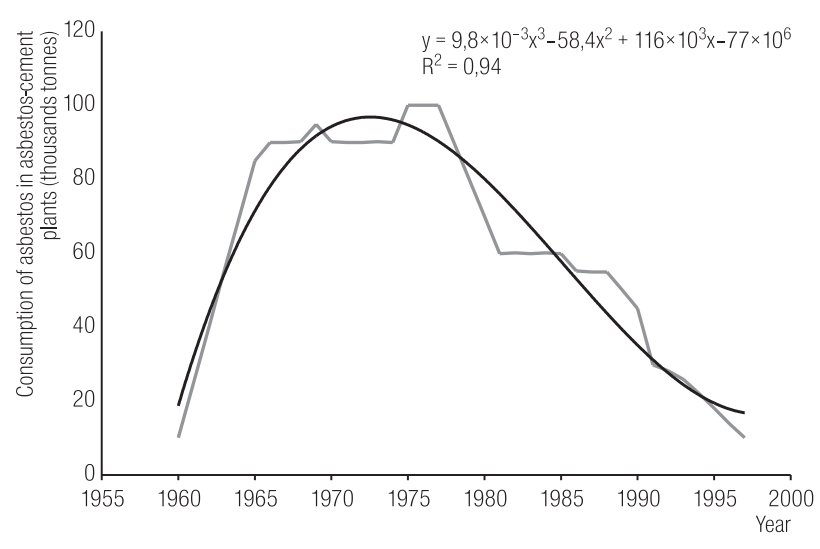

Fig. 1. Annual consumption of asbestos in asbestos-cement plants (in thousand tonnes) 


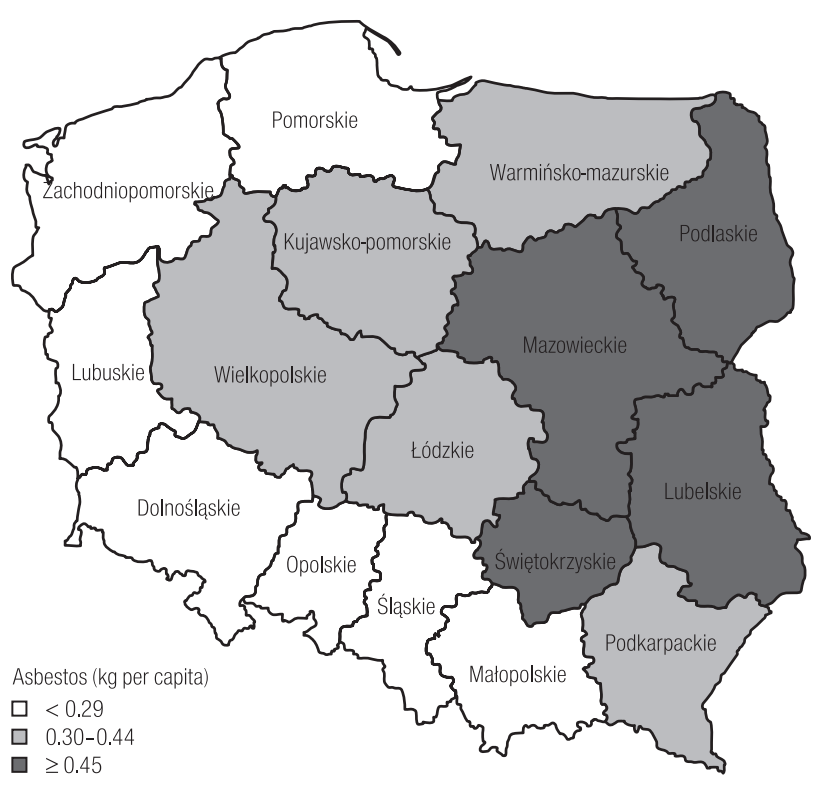

Fig. 2. Consumption of asbestos in terms of kg per capita, by provinces

boards were applied in the construction industry. In the cities, wall cladding panels were used mainly in prefabricated buildings, and their usage is estimated at about 3.5 million tonnes. The use of the panels in rural areas was 3-fold greater than in the cities [5]. Average consumption per 1 inhabitant of asbestos in Poland estimated in the 80's was about $1.7 \mathrm{~kg}$. The amount of asbestos in the installed asbestos-cement materials in different areas of Poland is shown in the map (Figure 2).

Three zones are clearly visible. The largest per capita amounts of asbestos in building construction materials were installed in the provinces located in the so-called eastern wall of Poland, where in the 70's the asbestoscontaining materials in the form of non-flammable roofing tiles (eternit) were obligatorily used to replace thatched roofs. Emissions of the asbestos fibres into the ambient air is a consequence of mechanical damage to the asbestos-containing tiles or boards and their corrosion caused by weather conditions. These materials are a source of continuous low emissions of asbestos fibres into the ambient air. The period of safe use of asbestos-cement is about 30 years in average conditions; these boards are

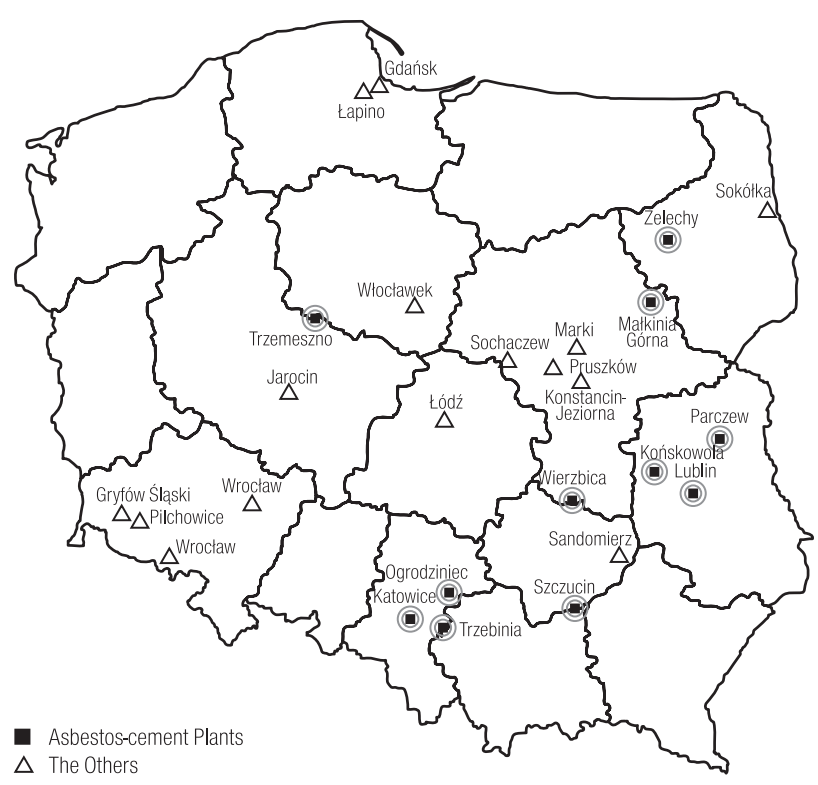

Fig. 3. Location of asbestos-processing plants

not degraded up to 60 years, although scanning electron microscope images show signs of visible damage on their surfaces. Acid rains occurring in industrialized regions greatly accelerate their corrosion [6].

Most environmentally polluted areas are those where asbestos processing plants were located, and asbestoscement plants in particular. In Poland in the period after World War II, asbestos-cement products were manufactured in seven large state-owned plants (Figure 3).

Asbestos pollution of the areas in the vicinity of asbestos-cement plants results from the fact that those plants occupied large areas necessary for the production of large-size goods, their storage and distribution. Industrial waste landfills also occupy large areas. Two of those plants used to distribute the waste among the neighbouring residents who used it to pave local roads, yards, school playgrounds and sports objects, and even for construction of farmstead buildings. Due to considerable environmental pollution in the area affected by one of the plants, there has been an ecological disaster manifested by excessive incidence of pleural mesothelioma among the residents $[7,8]$. 


\section{Airborne concentration of asbestos fibres in non-occupational environment}

To assess the degree of health risk to residents of an area, it is essential to determine the concentration of airborne asbestos fibres in the municipalities. As part of the government's program of eliminating asbestos from Poland, comprehensive measurements have been performed of the concentration of asbestos fibres in the air in different areas.

\section{MATERIAL AND METHODS}

\section{Sampling areas and sites of sampling}

In 2004-2010 in all provinces (voivodships) of Poland, 1634 sampling sites were designated where air samples were collected to determine the content of asbestos fibres. As much as 5962 samples were collected in 283 districts, i.e. $74.7 \%$ of all districts were included in the study (Table 1).

Table 1. Numbers of sampling sites and air samples by provinces

\begin{tabular}{lccc}
\hline \multicolumn{1}{c}{ Province } & $\begin{array}{c}\text { Administrative } \\
\text { districts } \\
(\mathrm{n})\end{array}$ & $\begin{array}{c}\text { Sampling } \\
\text { sites } \\
(\mathrm{n})\end{array}$ & $\begin{array}{c}\text { Air } \\
\text { samples } \\
(\mathrm{n})\end{array}$ \\
\hline Dolnośląskie & 15 & 84 & 252 \\
Kujawsko-pomorskie & 17 & 81 & 303 \\
Lubelskie & 21 & 126 & 477 \\
Lubuskie & 12 & 57 & 171 \\
Lódzkie & 23 & 181 & 881 \\
Małopolskie & 17 & 173 & 653 \\
Mazowieckie & 31 & 210 & 746 \\
Opolskie & 10 & 53 & 159 \\
Podkarpackie & 21 & 94 & 348 \\
Podlaskie & 17 & 61 & 224 \\
Pomorskie & 16 & 58 & 173 \\
Śląskie & 22 & 133 & 488 \\
Świętokrzyskie & 9 & 105 & 392 \\
Warmińsko-mazurskie & 16 & 58 & 215 \\
Wielkopolskie & 20 & 100 & 300 \\
Zachodniopomorskie & 16 & 60 & 180 \\
Total & 283 & 1634 & 5962 \\
\hline
\end{tabular}

Table 2. Numbers of sampling sites and air samples by type of area

\begin{tabular}{lccc}
\hline \multicolumn{1}{c}{ Area } & $\begin{array}{c}\text { Provinces } \\
(\mathrm{n})\end{array}$ & $\begin{array}{c}\text { Sampling sites } \\
(\mathrm{n})\end{array}$ & $\begin{array}{c}\text { Air samples } \\
(\mathrm{n})\end{array}$ \\
\hline Standard & 16 & 1511 & 5582 \\
After hurricane & 3 & 40 & 120 \\
$\begin{array}{l}\text { Asbestos-cement } \\
\text { plant vicinity }\end{array}$ & 6 & 83 & 260 \\
\hline
\end{tabular}

This number comprises 260 air samples collected at the sites designated in the areas of impact of nine former asbestos plants and 120 samples collected in the areas affected by the 2008 hurricane, which destroyed the eternit roofs of numerous houses and farm buildings (Table 2).

The samples were collected during the summer and autumn since July till October. Air temperature ranged from $+12^{\circ} \mathrm{C}$ to $+30^{\circ} \mathrm{C}$. Air samples were collected on days without rainfall, when the velocity of the wind was less than $1 \mathrm{~m} / \mathrm{sec}$. The number of sampling sites in the administrative units (districts) in different provinces was selected considering population density and the quantity of asbestos-containing materials accumulated in specified province. Literature data shows that considerable variations of the concentrations of asbestos fibres occur in the ambient air, depending largely on weather conditions.

Analysis of the number of measurements taken in specified sampling site showed that for ca. $24 \%$ of the sampling sites where the determination was performed only twice, mean concentration was below the detection limit of the method; when the number of the determinations was 3 , the corresponding proportion was reduced to ca. $12 \%$; the respective value for 4 measurements was as low as $3 \%$ (Table 3 ). Variations in asbestos fibres concentrations in samples of air collected at the same site cause that it is necessary to collect at least 3 to 4 samples at the intervals of more than several, or several dozen hours. 
Table 3. Number of sampling sites with asbestos concentration below the limit of detection in relation to number of air samples

\begin{tabular}{cccc}
\hline \multirow{2}{*}{$\begin{array}{c}\text { Air samples } \\
\text { collected at the } \\
\text { sampling site } \\
\text { (n) }\end{array}$} & $\begin{array}{c}\text { Sampling sites } \\
\text { (n) }\end{array}$ & \multicolumn{2}{c}{$\begin{array}{c}\text { Sampling sites with fibres } \\
\text { concentrations below } \\
\text { the limit of detection }\end{array}$} \\
\cline { 3 - 5 } & & $\mathrm{n}$ & $\%$ \\
\hline 3 & 146 & 11 & 23,9 \\
4 & 790 & 93 & 11,8 \\
\hline
\end{tabular}

\section{Measurements of asbestos fibres concentrations}

The method of sampling consists of passing a specified volume of air through a membrane filter using a pump with controlled air flow. The air was collected using a JSH 12000 stationary aspirator feeding it to $25-\mathrm{mm}, 0.8$ - $\mu \mathrm{m}$ pore dia. Sartorius filters at a filtration rate of $13 \mathrm{l} / \mathrm{min}$ during $100 \mathrm{~min}$, whereby it was possible to collect over $1 \mathrm{~m}^{3}$ of the air in relatively short time. The samplers were placed at the height of 1.5 metres above the ground level. The fibrous structures collected on the filter were identified using an optical polarization microscope (PLM) with positive phase contrast (PCM) and 600x total magnification. Respirable fibres, i.e. fibres $>5 \mu \mathrm{m}$ long with a diameter of $<3 \mu \mathrm{m}$, meeting the criterion of 1:3 diameter-to-length ratio were counted. To exclude non-asbestos fibres, the collected samples were examined in polarized light with crossed or parallel polarizers. The applied numerical method for determining the concentration of asbestos fibres using optical microscopy with phase contrast (PCM) according to the Polish standard PN 88/Z-04202/02 has been originally designed for the assessment of occupational exposure. The determination limit of this method is 0.01 fibres per $\mathrm{cm}^{3}$ of air, i.e. $10000 \mathrm{f} / \mathrm{m}^{3}$. The content of asbestos fibres in the ambient atmospheric air is much lower and usually ranges between a few and several thousand fibres in one $\mathrm{m}^{3}$ of air. Thus, it was necessary to modify the method so as to make it suitable for determination of asbestos fibres concentrations prevailing in the ambient air. A lower detection limit of 180 fibres in $1 \mathrm{~m}^{3}$ of air was used during the environmental measurements performed in this work. This lower limit of detection of the method was achieved by analyzing and counting respirable fibres on the surface of 500-800 cells of a Walton-Beckett graticule. All samples were analyzed by the Institute's laboratory accredited to use the analytical procedure.

\section{Statistical analysis}

All statistical analyses were performed using the R Software. The distribution of the number of asbestos fibres in samples collected from a single sampling site was found to follow the Poisson distribution. Generalized linear mixed model (GLMM) was constructed to investigate the relationship between asbestos concentration and its main determinants and the random components ( $\mathrm{R}$ package lme4). Both the fixed and random effects were incorporated in the mixed effect model. We used Poisson distribution for error distribution with log link and Gaussian error distribution for random effect in GLMM. We also incorporated offset term to convert fibres count into fibres concentration [9]. The fixed effects provide estimates of average asbestos concentration from all sampling sites in a given group (e.g., province), while the random effects make it possible to estimate the variability of concentrations between particular sampling sites. Estimated average asbestos concentration at a sampling site can be interpreted as a geometric mean calculated from the mean concentrations (arithmetic mean) recorded for that location. Variability between results for particular sampling sites is related to the amount of asbestos and weather conditions.

We have used GLMM to estimate average asbestos concentrations in districts and to evaluate the relationship between the amount of asbestos and the mean asbestos fibres concentration in the air samples examined. Descriptive statistics, such as measures of central tendency (arithmetic mean - AM) and measures of dispersion (geometric standard deviation - SD, range) were calculated for each of the main determinants. 


\section{RESULTS}

Of the total of 5962 air samples collected all over Poland, asbestos fibres concentration was below the limit of detection in as many as 1537 samples (25.8\%). This percentage varied from $15.8 \%$ to approx. $41 \%$ between particular provinces. For the total of 1634 sampling sites, asbestos fibres concentrations below the limit of detection were recorded at 128 of the sites. The mean asbestos fibres concentration in Poland was estimated to be $492 \mathrm{f} / \mathrm{m}^{3}$ (95\% CI: 467-518). In the provinces, the mean asbestos concentrations were below $800 \mathrm{f} / \mathrm{m}^{3}$, including six districts where the levels below $400 \mathrm{f} / \mathrm{m}^{3}$ were found (Table 4).

Table 4. Average concentration of asbestos fibres $\left(\mathrm{f} / \mathrm{m}^{3}\right)$ by provinces

\begin{tabular}{|c|c|c|c|c|}
\hline \multirow[t]{2}{*}{ Province } & \multicolumn{2}{|c|}{ Concentration $\left(\mathrm{f} / \mathrm{m}^{3}\right)$} & \multicolumn{2}{|c|}{$\begin{array}{l}\text { Sampling sites with } \\
\text { fibres concentrations } \\
\text { below the limit } \\
\text { of detection }\end{array}$} \\
\hline & $\begin{array}{c}\text { arithmetic } \\
\text { mean }\end{array}$ & $95 \% \mathrm{CI}$ & $\mathrm{n}$ & $\%$ \\
\hline Dolnośląskie & 247 & $195-313$ & 11 & 13.1 \\
\hline $\begin{array}{l}\text { Kujawsko- } \\
\text { Pomorskie }\end{array}$ & 337 & $271-421$ & 9 & 11.1 \\
\hline Lubelskie & 677 & $570-804$ & 10 & 7.9 \\
\hline Lubuskie & 611 & $473-790$ & 5 & 8.8 \\
\hline Łódzkie & 666 & $579-767$ & 15 & 8.3 \\
\hline Małopolskie & 541 & $466-628$ & 33 & 19.1 \\
\hline Mazowieckie & 609 & $535-694$ & 8 & 3.8 \\
\hline Opolskie & 146 & $106-203$ & 13 & 24.5 \\
\hline Podkarpackie & 312 & 254-384 & 6 & 6.4 \\
\hline Podlaskie & 410 & $320-526$ & 3 & 4.9 \\
\hline Pomorskie & 518 & $404-664$ & 3 & 5.2 \\
\hline Śląskie & 679 & $577-800$ & 0 & 0 \\
\hline Świętokrzyskie & 709 & $591-851$ & 0 & 0 \\
\hline $\begin{array}{l}\text { Warmińsko- } \\
\text { Mazurskie }\end{array}$ & 375 & $290-484$ & 2 & 3.4 \\
\hline Wielkopolskie & 393 & $323-478$ & 9 & 9.0 \\
\hline $\begin{array}{l}\text { Zachodnio- } \\
\text { pomorskie }\end{array}$ & 411 & $320-529$ & 1 & 1.7 \\
\hline Total & 492 & $467-518$ & 128 & 7.8 \\
\hline
\end{tabular}

$S_{y}^{2}=0.76$ : between-area variance component.

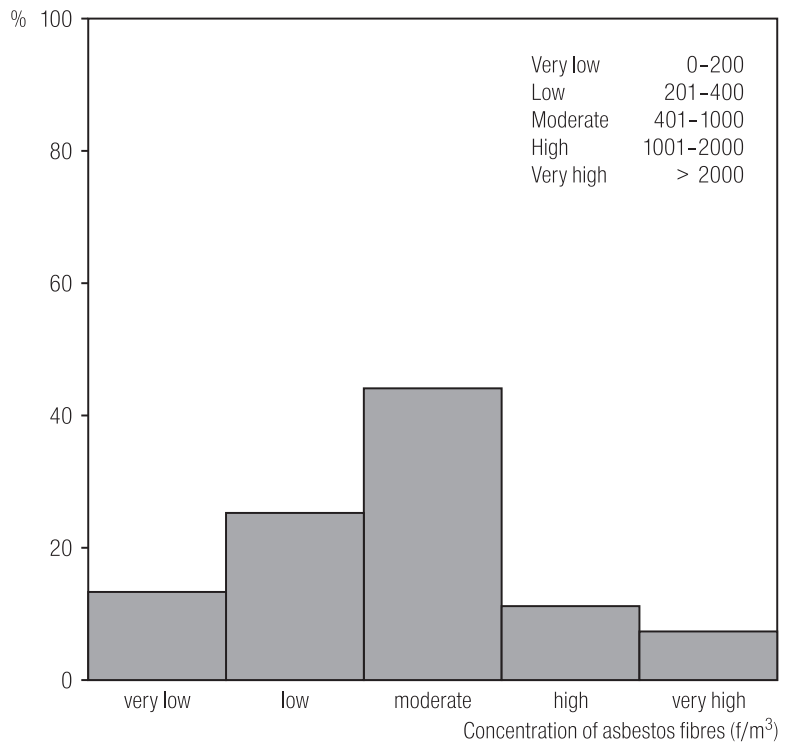

Fig. 4. Distribution of mean asbestos fibres concentrations in sampling sites in Poland

All-Poland distribution of airborne asbestos fibre concentrations was as follows: low concentrations were noted in 622 sampling sites (38\% of all sites), moderate concentrations $\left(400-1000 \mathrm{f} / \mathrm{m}^{3}\right)$ in $44 \%$ of sites and high concentrations (over $1000 \mathrm{f} / \mathrm{m}^{3}$ ) were recorded in approx. $18 \%$ of the sampling sites (Figure 4). Assuming the admissible concentration levels to be below $1000 \mathrm{f} / \mathrm{m}^{3}$ of air, which in terms of the occupational hygiene standards corresponds to $0.001 \mathrm{f} / \mathrm{cm}^{3}$, one can note that the admissible asbestos fibres concentration would apply to as much as $82 \%$ of the sampling sites (Figure 4).

Analysis by sampling site revealed that the mean asbestos fibres concentration calculated for 5582 samples from 1511 sites all over Poland equalled 472 f/m $/ \mathrm{m}^{3}$ (95\% CI: 445-502). For the total of 120 air sample measurements performed over the hurricane-affected area, this concentration approximated $585 \mathrm{f} / \mathrm{m}^{3}$ (95\% CI: 403-850). The highest mean asbestos fibres concentration of $732 \mathrm{f} / \mathrm{m}^{3}$ (95\% CI: 527-1016) was noted in the areas adjacent to the former asbestos processing plants, where 260 measurements were made in 83 sampling sites. This concentration was found to be significantly higher than respective values for other areas (Table 5). 
Table 5. Average concentration of asbestos fibres $\left(\mathrm{f} / \mathrm{m}^{3}\right)$ in relation to type of area

\begin{tabular}{|c|c|c|c|c|}
\hline \multirow{3}{*}{ Area } & \multicolumn{2}{|c|}{ Concentration $\left(\mathrm{f} / \mathrm{m}^{3}\right)$} & \multirow{2}{*}{\multicolumn{2}{|c|}{$\begin{array}{l}\text { Sampling sites with } \\
\text { fibres concentrations } \\
\text { below the limit } \\
\text { of detection }\end{array}$}} \\
\hline & \multirow[t]{2}{*}{$\begin{array}{l}\text { arithmetic } \\
\text { mean }\end{array}$} & \multirow[t]{2}{*}{$95 \% \mathrm{CI}$} & & \\
\hline & & & $\mathrm{n}$ & $\%$ \\
\hline Standard & 472 & $445-502$ & 120 & 7.9 \\
\hline After hurricane & $585^{*}$ & $403-850$ & 1 & 2.5 \\
\hline $\begin{array}{l}\text { Asbestos- } \\
\text { cement plant } \\
\text { vicinity }\end{array}$ & $732 * *$ & $527-1016$ & 7 & 7.8 \\
\hline
\end{tabular}

${ }^{*} \mathrm{p}=0.27,{ }^{* *} \mathrm{p}=0.01$.

$S_{y}^{2}==0.89$ : between-area variance component.

The asbestos in construction elements installed in buildings and facilities is the source of environmental exposure. The observed relationship between the amount of asbestos in the installed construction elements and asbestos fibres concentration in outdoor air has been described using the equation in Figure 5. The results indicate that an increase in asbestos consumption by 1 tonne $/ \mathrm{km}^{2}$ in a given province resulted in mean asbestos fibres concentration increase of $50.3 \mathrm{f} / \mathrm{m}^{3}$.

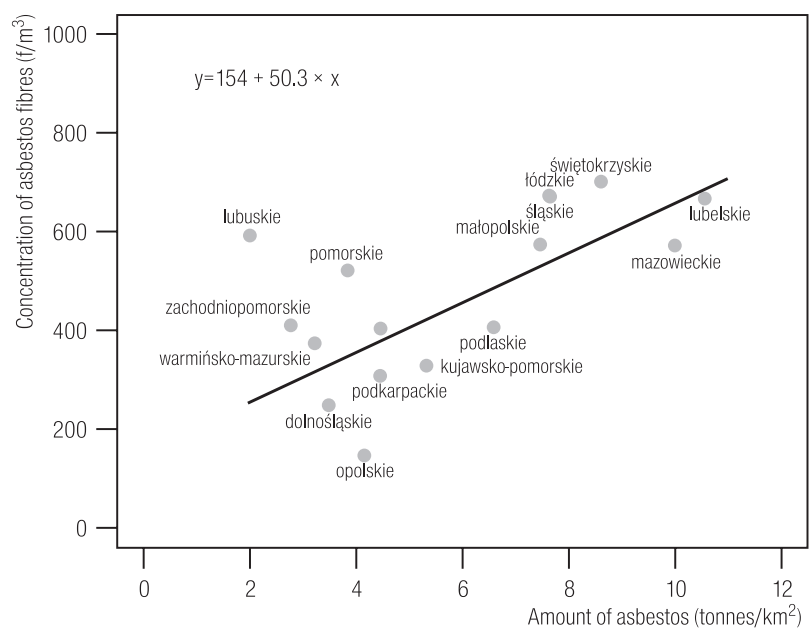

Fig. 5. Relationship between amount of asbestos in the installed building materials and concentration of asbestos fibres in the air by provinces

\section{DISCUSSION}

The report discusses current levels of environmental asbestos pollution in Poland. The estimates have been based on data regarding the import and consumption of asbestos and accumulation of asbestos-containing materials in particular provinces as well as on measurements of asbestos fibres concentration in outdoor air.

Over the period of more than 50 years (since 1946 till 1997), approximately 2 million tonnes of asbestos, mostly chrysotile, had been imported to Poland. Amphiboles made up 4-5\% of the imported raw material (incl. $4 \%$ of crocidolite). As much as $85 \%$ of the imported asbestos was used in the production of construction materials, mostly asbestos cement sheets applied as roofing and wall cladding elements. In contrast to Western Europe, soft asbestos products, asbestos spraying or asbestos-containing thermal or acoustic isolation [10], have not been used in Polish construction industry.

The present environmental pollution with asbestos in our country is mostly due to release of asbestos fibres from asbestos-containing construction elements in buildings. A significant contribution is also that of environmental pollution in areas located in the vicinity of former asbestos processing plants.

Asbestos consumption per capita is a useful parameter to analyse the population-level environmental exposure and consequently to forecast the incidence of pleural mesothelioma. In Poland, between 1960's and 1980's, the mean asbestos consumption per capita was estimated at $1.7 \mathrm{~kg}$, ranging from $0.5 \mathrm{~kg}$ in 1960 to $2.3 \mathrm{~kg}$ in 1980 . In other countries, the respective values for 1980 were as follows: $5.6 \mathrm{~kg}$ in Germany, $3.4 \mathrm{~kg}$ in Japan, $3.7 \mathrm{~kg}$ in former Czechoslovakia and $3.2 \mathrm{~kg}$ in Italy [11,12]. In 1994, asbestos consumption per capita ranged from $0.004 \mathrm{~kg}$ in Northern Europe (Denmark, Finland, Sweden) and 0.6 in Central Europe (Poland, Czechoslovakia, Hungary, Romania, Bulgaria) to 2.4 in the former Soviet Union [13]. The highest levels were noted during the period of 1970-1989. 
In comparison with the countries of Northern and Western Europe, the most intense asbestos consumption in Poland was recorded much later and the level was much lower in general [14].

The studies on the incidence of mesothelioma and asbestos consumption that were conducted in 10 countries of Western Europe and in Japan revealed that a $1 \mathrm{~kg}$ increase in asbestos consumption per capita resulted in a yearly increase in mesothelioma incidence by 6 cases per 1 million inhabitants [15]. The findings obtained by Tossavainen (2004) indicate that asbestos consumption of $2.8 \mathrm{~kg}$ per capita will lead to ca. 18 cases of mesothelioma per 1 million exposed inhabitants, and thus the amount of 170 tonnes of asbestos produced and used may in future account for one death from pleural mesothelioma [16]. A recent report based on data from 33 countries revealed a strong relationship between asbestos consumption between 1960 and 1969 and mortality from asbestos-related diseases in the period of 2000-2004 [17]. According to the authors, historical asbestos consumption was a significant predictor of death rates for all mesotheliomas in both sexes, and high levels of asbestos consumption corresponded with high log-mortality rate. In Poland, the highest levels of asbestos consumption were recorded 10 years later; therefore, increased death rates from asbestos-related cancers may be expected between 2010 and 2020 .

Since, contrary to the studies on occupational exposure, there have been only a few reports on domestic and environmental exposure to asbestos, it is difficult to discuss the present findings in relation to other observations. Moreover, only a few authors used the levels of asbestos concentration in outdoor air in order to assess the health effects of exposure $[10,18]$. The difficulty in interpreting the results will also arise from different characteristics of sampling sites and different measurement strategies. Corn [19] pointed out fundamental differences in interpretation of results obtained using phase contrast microscopy (PCM) to measure asbestos fibres concentration in work environment and non-occupational settings. It is the actual method used for statistical analysis that is most significant in the interpretation and comparison of the study results [20]. Our study has revealed that the number of air samples collected at sampling sites within a given territory plays a significant role in the evaluation of the level of environmental exposure in that area. The large number of measurements (ca. 6000) made it possible to define the optimum number of samples to be collected at a single sampling site and to substantially limit the number of sites with concentration levels below the limit of detection. The variability in the number of asbestos fibres recorded in several measurements at a given sampling site points to the necessity of collecting at least three air samples in this location at time intervals of several to several dozen hours. In general, accessible literature reports ambient asbestos air concentrations in a wide range of values from several to about tens of thousands fibres per $\mathrm{m}^{3}$. The high levels of asbestos fibres concentration that were recorded up to 1980's in urban areas must have been associated with the use of asbestos in clutches and brake linings of motor vehicles.

During this period, airborne asbestos fibres concentrations in other countries approached the levels of $4600 \mathrm{f} / \mathrm{m}^{3}$ in Austria, from 200 up to $5000 \mathrm{f} / \mathrm{m}^{3}$ in Germany, from 200 to $4000 \mathrm{f} / \mathrm{m}^{3}$ in Canada [21] and from 4000 to as many as $11100 \mathrm{f} / \mathrm{m}^{3}$ in Japan [22]. The measurements of asbestos fibres concentration carried out in the vicinity of expressways in the US showed levels approximating $3300 \mathrm{f} / \mathrm{m}^{3}$, and the concentrations recorded in large urban areas equalled $900 \mathrm{f} / \mathrm{m}^{3}$ [23]. The recently published results of measurements of asbestos fibres concentration in the urban environment of Teheran, Iran, showed the average concentration of $3400 \mathrm{f} / \mathrm{m}^{3}$ [24]. The authors suggest that the recorded high levels of airborne asbestos fibres were attributable mainly to asbestos from automobile brakes and clutches. The present report discusses the findings of measurements conducted over the period of 2004-2010, that is 6-12 years since asbestos use had been 
banned in Poland. They indicated relatively low levels of mean airborne asbestos fibres concentrations. As revealed by the results of our study analysing data on almost 6000 air samples, the mean asbestos fibres concentration in Poland approximates $492 \mathrm{f} / \mathrm{m}^{3}$ (95\% CI: 467-518), ranging from 146 to $709 \mathrm{f} / \mathrm{m}^{3}$ across provinces. These findings correspond with the relatively low level of asbestos consumption and are consistent with the results of measurements conducted from 1990 onwards by other researchers.

In the US, the estimated outdoor asbestos concentrations are generally less than $500 \mathrm{f} / \mathrm{m}^{3}$, while in urban areas, they can be as high as $2000 \mathrm{f} / \mathrm{m}^{3}$ [19]. A study concerning asbestos fibres concentration in non-occupational Korean areas showed levels of $600 \mathrm{f} / \mathrm{m}^{3}$ in urban areas and $300 \mathrm{f} / \mathrm{m}^{3}$ in rural areas [25].

The values of airborne asbestos fibres concentration that were recorded in our study were generally consistent with the data from measurements carried out in Poland in 2007-2008, and in the majority of samples did not exceed the level of $1000 \mathrm{f} / \mathrm{m}^{3}$. A report from Upper Silesia suggests that in areas adjacent to buildings where asbestos elements can be found, this concentration may range from $1000 \mathrm{f} / \mathrm{m}^{3}$ to $9000 \mathrm{f} / \mathrm{m}^{3}$ [26]. However, the $1000 \mathrm{f} / \mathrm{m}^{3}$ level of the detection limit of the method used by the authors precludes determining asbestos fibres concentration in non-occupational settings.

The parliamentary act of 2010 [27] allows a new method of eliminating asbestos-cement products from the environment by crushing them and crumbling to $5 \mathrm{~mm}$ particles in a mobile container where they are then subject to microwave treatment. This unprecedented way of handling asbestos-containing materials, which is contrary to scientific evidence and to the recommendations of the government project for asbestos elimination in Poland, may eventually contribute to increasing environmental pollution with asbestos. We presume that any action in this respect should be undertaken with caution, and at the present levels of environmental exposure, a better alternative to abrupt "elimination" of asbestos in mobile containers would be to maintain the status quo with respect to the already existing construction elements that contain asbestos.

\section{CONCLUSIONS}

At present, asbestos exposure is associated mainly with outdoor air pollution from asbestos-containing construction materials used in buildings.

Asbestos consumption per capita and the recorded moderate levels of asbestos fibres concentration in atmospheric air point to a relatively low level of environmental asbestos pollution in Poland.

Areas in the vicinity of former asbestos processing plants exhibit significantly higher asbestos fibres concentrations than the rest of the country.

The findings revealed territorial variability in asbestos consumption that has impact on asbestos fibres concentration. An increase in asbestos consumption by 1 tonne $/ \mathrm{km}^{2}$ in a given country district resulted in mean asbestos fibre concentration increasing by $50.3 \mathrm{f} / \mathrm{m}^{3}$.

It is important to develop well defined criteria for measuring asbestos fibres concentration in the environment. In our experience the result of a single air sampling in a given location is encumbered with an error that precludes correct interpretation of the level of environmental asbestos exposure in that area.

\section{ACKNOWLEDGEMENTS}

The authors would like to thank Zofia Nikodemska for monitoring of the field study, especially for exceptional technical assistance in preparing a report and the final version of this article, and Barbara Michalska for handling all administrative matters. We thank also laboratory staff for intense work, in particular Dr. Stella Bujak-Pietrek, Grażyna Frątczak and Alicja Roszkowicz, whose assistance was invaluable for determination of asbestos fibres concentration. 


\section{REFERENCES}

1. The Act of 19 June 1997 on the ban of the use of asbestoscontaining products (unified text). J Laws 2004, No. 3, item 20 as amended (Jan 12, 2004) [in Polish].

2. Dyczek J. Asbestos-cement products, their characteristics, application, degradation of asbestos-cement boards. In: SzeszeniaDąbrowska N, ed. Proceedings of the Seminar for the State Sanitary Inspectors on Asbestos environmental pollution. Risk to human health. 2007 Oct 25; Wrocław, Poland. Łódź: Nofer Institute of Occupational Medicine; 2007. p. 16-24 [ in Polish].

3. Kadlewicz K. Testing of airborne asbestos fibre concentrations in ambient atmospheres of workplaces and non-occupational environments. Res Rep Mining Environ 2009;4:19-40 [in Polish].

4. Szeszenia-Dąbrowska N, Świątkowska B, Szubert Z, Wilczyńska U. Asbestos in Poland. Occupational Health Problems. Int J Occup Med Environ Health 2011;24(2):142-52. DOI 10.2478/s13382-011-0020-4.

5. Dyczek J. Characteristics, properties and applications of asbestos. In: Dyczek J, ed. Proceedings of the Conference on Conditions for safe use of asbestos-containing buildings and removal of selected asbestos-containing products. 2004 Sep 9-10, Cracow, Poland. Kraków: AGH; 2004. p. 9-30 [in Polish].

6. Dyczek J. Surface of asbestos-cement (AC) roof sheets and assessment of the risk of asbestos release. In: Dyczek J, ed. Proceedings of the International Seminar on Asbestos Risk Reduction \& Measurement of Asbestos Fibre Concentration. 2006 Sep 28-29, Cracow. Poland. Kraków: AGH; 2006. p. $57-63$.

7. Szeszenia-Dąbrowska N, Siuta J, eds. Environmental asbestos pollution. Health effects and their prevention. Łódź: Nofer Institute of Occupational Medicine; 1998 [in Polish].

8. Szeszenia-Dąbrowska N, Wilczyńska U, Szymczak W, Laskowicz K. Environmental exposure to asbestos in asbestos cement workers: a case of additional exposure from indiscriminate use of industrial wastes. Int J Occup Med Environ Health 1998;11(2):171-7.

9. Brown H, Prescott R. Applied mixed models in medicine. New York: John Wiley\&Sons Ltd.; 2001.
10. Bourdès V, Boffetta P, Pisani P. Environmental exposure to asbestos and risk of pleural mesothelioma: review and metaanalysis. Eur J Epidemiol 2000;16:411-7.

11. Virta R. Worldwide asbestos supply and consumption trends from 1990 to 2003. US Geological Survey, 2006 [cited Sep. 12, 2011]. Available from URL: http://pubs.usgs.gov/ circ/2006/1298/c1298.pdf.

12. United States Census Bureau (USCB). Population Division: International Data Base. [cited Sep. 12, 2011]. Available from URL http://www.census.gov/ipc/www/idb/country.php

13. Albin M, Magnani C, Krstev S, Rapiti E, Shefer I. Asbestos and Cancer: An Overview of Current Trends in Europe. Environ Health Perspect 1999;107(2):289-98.

14. Nishikawa K, Takahashi K, Karjalainen A, Wen Ch-P, Furuya S, Hoshuyama T, et al. Recent Mortality from Pleural Mesothelioma, Historical Patterns of Asbestos Use, and Adoption of Bans: A Global Assessment. Environ Health Perspect 2008;116(12):1675-80.

15. Takahashi K, Huuskonen MS, Tossavainen A, Higashi T, Okubo T, Rantanen J. Ecological relationship between mesothelioma incicence/mortality and asbestos consumption in the Western Countries and Japan. J Occup Health 1999;41:8-11.

16. Tossavainen A. Global use of asbestos and the incidence of mesothelioma. Int J Occup Environ Health 2004;10:22-5.

17. Lin RT, Takahashi K, Karjalainen A, Hoshuyama T, Wilson D, Kameda T, et al. Ecological association between asbestos-related diseases and historical asbestos consumption: an international analysis. Lancet 2007;369:844-9.

18. Magnani C, Dalmasso P, Biggeri A, Ivaldi C, Mirabelli D, Terracini B. Increased risk of malignant mesothelioma of the pleura after residential or domestic exposure to asbestos: A case-control study in Casale Monferrato, Italy. Environ Health Perspect 2001;109(9):915-9.

19. Corn M. Airborne concentrations of asbestos in non-occupational environments. Ann Occup Hyg 1994;38(4):495-502.

20. Lange JH, Lange PR, Reinhard TK, Thomulka KW. A study of personal and area airborne asbestos concentrations during 
asbestos abatement: A statistical evaluation of fibre concentration data. Ann Occup Hyg 1996;40(4):449-66.

21. International Program for Chemical Safety. Asbestos and Other Natural Mineral Fibres. Environmental Health Criteria No. 53. Geneva: WHO; 1986.

22. Kohyama N. Airborne asbestos levels in non-occupational environments in Japan. In: Bignon J, Peto J, Saracci R, eds. Non-occupational Exposure to Mineral Fibres. IARC Scientific Publications No. 90. Lyon: International Agency for Research on Cancer; 1989. p. 262-76.

23. Bignon J. Mineral fibres in the non-occupational environment. In: Bignon J, Peto J, Saracci R, eds. Non-occupational Exposure to Mineral Fibres (IARC Scientific Publications No. 90). Lyon: International Agency for Research on Cancer; 1989. p. 3-29.
24. Kakooei H, Yunesian M, Marioryad H, Azam K. Assessment of airborne asbestos fiber concentrations in urban area of Tehran, Iran. Air Qual Atmos Health 2009;2:39-45.

25. Lim HS, Kim JY, Sakai K, Hisanaga N: Airborne asbestos and non-asbestos fiber concentrations in non-occupational environments in Korea. Ind Health 2004;42:171-8.

26. Krakowiak E, Górny RL, Cembrzyńska J, Sąkol G, BoissierDraghi M, Anczyk E. Environmental exposure to airborne asbestos fibres in a highly urbanized city. Ann Agric Environ Med 2009;16:121-8.

27. The Act of 22 January 2010 amending the Waste Act and other laws. J Laws 2010, No 28, item 145 [in Polish].

This work is available in Open Access model and licensed under a Creative Commons Attribution-NonCommercial 3.0 Poland License - http://creativecommons.org/ licenses/by-nc/3.0/pl/deed.en. 